\title{
Are There Things Only Artists Can Do? Archiving through a treadmill ${ }^{1}$
}

\author{
Carolina Felice Bonfim \\ Free University of Brussels, Brussels, Belgium \\ E-mail: carolina.felice.bonfim@ulb.ac.be
}

\section{Abstract}

This article seeks to share the methods and strategies of the practice-based research project Ninety movements on TECHNOGYM G6508D. The research dissects the act of running in all its dimensions by fragmenting, archiving, incorporating, and highlighting what is unique and personal in each gesture and each way of moving. Ninety movements on a Technogym G6508D is a continuation of Carolina Bonfim's recent artistic practice, which explores the relationship between the body and the archive through a visual-arts approach.

\section{Keywords}

archive, body, embodiment, methodology, practice-based research.
Este artigo busca compartilhar os métodos e as estratégias do projeto de pesquisa baseado na prática artística Ninety movements on a Technogym G6508D. Nessa pesquisa me concentro no ato de correr a fim de levá-lo ao extremo: fragmentá-lo, arquivá-lo, incorporá-lo e destacar o que há de único e pessoal em cada gesto e em cada forma de movimento. $\mathrm{Ni}$ nety movements on a Technogym G6508D é a continuação de uma linha de trabalho que venho desenvolvendo ao longo dos últimos anos que, desde uma perspectiva pautada nas artes visuais e na performance, tem como tema central o corpo como arquivo.

arquivo, corpo, incorporação, metodologia, pesquisa baseada na prática. 
The present contribution offers a self-reflexive analysis of the creative processes of Ninety movements on TECHNOGYM G6508D, a project carried out within the framework of my (practice-based) doctoral research ${ }^{2}$. Ninety movements is a study on running - the exercise is done on a Technogym G6508D treadmill. The project continues a line of work I have been developing over the last couple of years which addresses the body as a living archive ${ }^{3}$. I mainly focus on the question of how my own body can incorporate gestures, and other people's body language. What does the act of archiving the body mean? How does this operation differ from archiving objects and/or documents? How should we approach archives that draw their content from the body, from a set of operations and methods that do not necessarily aspire to authenticity or fidelity? How can the other be embodied, archived, and transmitted? How can the visual arts help to articulate intangible archives? What approaches are needed when dealing with materials that appear to be 'unarchivable'?

1 This article was originally published in the Fall 2020 issue of FORUM+ journal for research and arts in Belgium and the Netherlands: https://www.forum-online.be, accessed 28 March 2020.

$2 \mathrm{PhD}$ in Arts \& Arts Sciences from the Université Libre de Bruxelles and l'École Nationale Supérieure des Arts Visuels de La Cambre. Within this doctoral research, I have developed three artistic projects: Ninety movements on TECHNOG YM G6508D; Not Himself, not herself, not itself; and Laboratory on ways to search, destroy, invent, be and perform the archive.

3 This correlation between the archive and the body has been increasingly emphasized in the last decade, especially by a number of artists and thinkers from different fields who consider the human body as a repository of knowledge, even as a place of heritage, and as a vehicle capable of linking past, present, and future. The body as an archive or body-archive is a topic at the crossroads between the visual arts, performance, theatre, dance, music, and the humanities. This text does not intend to present a state of the art about this subject, but I would like to mention the following texts: The Body and the Archive (1986) by Allan Sekula, Dança da Guerra: Arquivo-Arma (1983) by Júlio Tavares; The Archive and the Repertoire: Performing Cultural Memory in the Americas (2003) by Diana Taylor; The Body as Archive: Will to Re-Enact and the Afterlives of Dances (2010) by André Lepecki.
These are the very questions I have tried to answer through my artistic research. Indeed, my interest in the notion of the body as an archive led me to start a practice-based PhD programme as a potential way to gain a broader understanding of the poetics behind this phenomenon. In the following, I will first describe the creative process of Ninety movements on TECHNOGYM G6508D, emphasizing the methodologies that have been used. I will then briefly discuss the artistic work created along this research, and subsequently, I will share some comments and experiences resulting from this project.

\section{Stage 0: Before starting}

The creative process of Ninety movements on TECHNOGYM G6508D began without any predetermined methodology. Because the methodological choices were only understood as such when the work was finalized, each stage of the process was recorded in detail. In fact, in the project I sent along with my doctoral application, I neither specified the methods and actions of the artistic research, nor did I indicate its expected outcome, as my work is based on spontaneity and intuition. The aim of the research project was indeed to carry out an experiment with different bodies intertwined with archival practices, yet without determining what the actions would be. A certain kind of serendipity or openness was necessary to start a PhD in the arts.

\section{Stage 1: Exploring the field}

In order to conduct my doctoral research, I moved to Brussels. My first strategy to start my creative process was to walk around the city. After a few months, I had observed and perceived many things: landscapes, architecture, nature, animals, people, sounds, languages, etc. And among all these things, my attention was focused on one aspect in particular: people moving frantically behind the window of a gym near my home. Every day, when I went out for a walk, no matter what the hour was, I saw them. It was like a big stage that brought together a variety of bodies that I could never have found 
anywhere else. Not to mention the fact that these bodies were there twenty-four hours a day, seven days a week, constantly on the move. Intrigued by this scene, I joined the gym on 13 May 2016. Even though I was not used to going to places like this for my workout session, I did not hesitate to step into the unknown. From then on, I stopped my walks in the city to focus on the exploration of this new place.

On the very first day, I chose a treadmill that gave me a panoramic view of the gym. Of all the things I saw, what intrigued me the most were the bodies running in front of me. It was like watching a choreography of the same action performed in different ways, where each body shows its own gestural vocabulary. I was fascinated by these bodies making mechanical and repetitive movements that, in every detail, revealed something personal. Thus, while carrying out my study, I decided to focus on the act of running in all its dimensions: to fragment, archive, incorporate, highlight what is unique and personal in each gesture and each way of moving. In order to observe these running bodies, I ran on one of the treadmills in that room for ninety days.

Figure 1. Spy camera: pen, 2017.

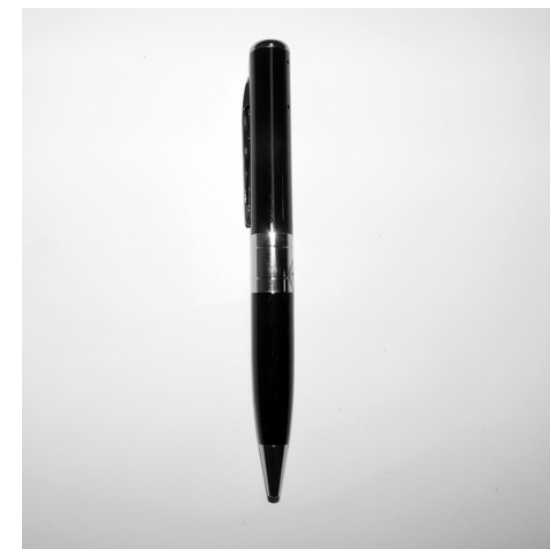

Source: Photo by Carolina Bonfim
Figure 2. Spy camera: keychain, 2017.

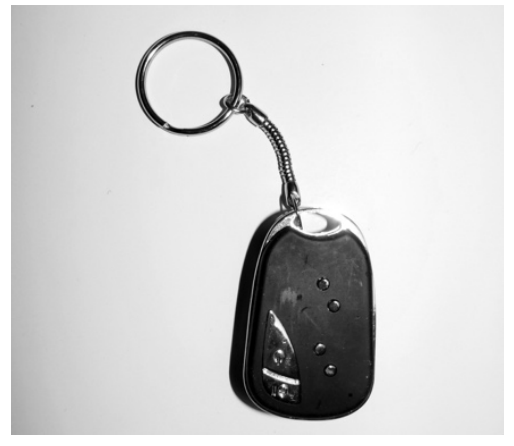

Source: Photo by Carolina Bonfim

Figure 3. Spy camera: glasses, 2017.

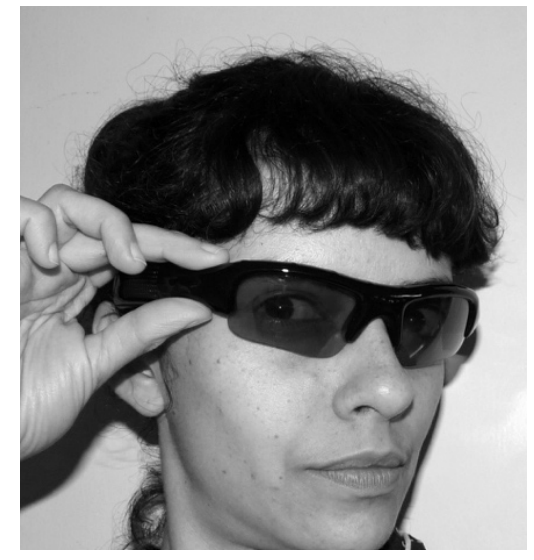

Source: Photo by Carolina Bonfim

Stage 2: Appropriation

Every day, I repeated the same action: I arrived at the gym and ran on the same treadmill. I was always facing the same scenery: a row of twelve other treadmills and a large mirror. Once I turned on my treadmill, I randomly chose a body in front of me. First, I archived my object of study using spy recording tools, such as glasses, a pen and a keychain, in order to keep track of the observed body without being seen. In the beginning, I wanted to record everything, so I would not lose any details, but I finally understood that only a two-minute take was enough. After recording it, I tried to repeat the movements by observing the target body, dividing it into reference points in order to identify the gestural and rhythmic mechanisms and to keep a precise memory of the movement to be reproduced. These reference points - face, mouth, shoulders, knees, and legs - were parts of the body that provided 
relevant information for me to reconstruct afterwards. Besides these specific body parts, I also examined limb joints, geometry of proportions, mechanical actions of muscles, conditions of balance, locomotor movements, and so on. The deciphering of these running bodies in my own body is what I call the appropriation of the other. During my research at the gym, I was fascinated to feel my body perform an everyday action like running in ways I never imagined before. When I got home after 'training', I organized the recordings and photos I took, then I made drawings and wrote down my experience in a notebook which could be considered a diary - documenting everything that happened to me at the gym.

\section{Stage 3: Incorporation}

The next step was to fix, incarnate, or simply incorporate the other bodies. What does incorporating the other mean? From a practical point of view, I understand incorporation as a process of altering one's own body through its constant fragmentation and recomposition. In this study, the dynamics of incorporation require a routine to continually reexamine everything that is learned during the previous steps. As a new body was added to my archive every day, the daily repetition of all body movements was crucial. To this end, I first repeated a movement by watching its corresponding video. After a few days of performing that same action, I noticed the movements came to me more naturally, without having to think about it, and watching the recording of the movement was no longer necessary. Repetition and appropriation are a regular process; an enactment to be practiced over and over again, day after day, in order to assimilate and make the other merge with oneself.
Figure 4. Carolina Bonfim, Catalogue de mouvements, 2017, 180 digital prints on A4 paper, binder, wood, metal, $100 \times 68 \times 45 \mathrm{~cm}$, MARCO,

Museo de Arte Contemporánea de Vigo.

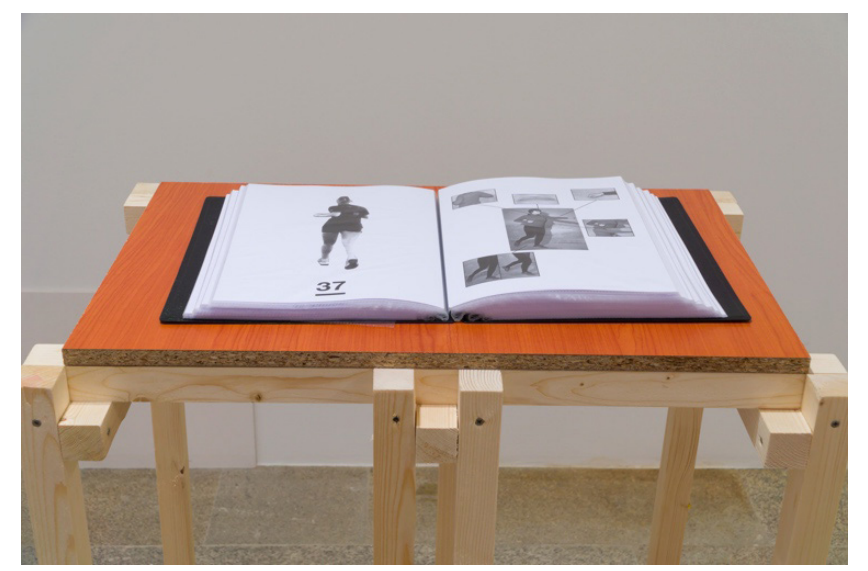

Source: Photo by Enrique Touriño.

\section{Stage 4: Transmission}

After spending ninety days at that gym, I looked back at all the collected material in order to reflect on how to transform these experiences into artworks to be shown in an exhibition. I asked myself what I was looking for and how I wanted to communicate what I had done so far. Consequently, I began looking for artists who had already worked on the theme of the gym. Starting with a state of the art is something I have been doing for years. This is an important method in order to inspire me, to establish a sort of dialogue on a common subject and then to develop my own point of view. My research showed that the subject of gyms has been treated through different approaches, by various artists such as Guillaume Bijl (Gym, 1983 and Fitness Center, 1985), Matthew Barney (Drawing Restraint, 1988), Collier Schorr (The Brothers A.M \& M., 2003), Lee Walton (Baseball's Cartographer, 2004), Mads Lynnerup (Plastic Gymnastic, 2012), Alexandra Bachzetsis (The Stages of Staging, 2013) or Aldo Giannotti (The Museum as a Gym, 2016). With this in view, I realised that for ninety days my target had not been the gym as a place, even though it is a rich field of study, but rather the bodies I observed being materialized on the treadmill. I therefore chose an intermediate way of transmitting my experience at the gym without denying that it took place in a 
gym, nor limiting it to this space either. Since my overall doctoral project dealt with the archiving of the body, it seemed relevant to me to define a formal way that could outline all these stages, that is, appropriation, incorporation, and transmission.

Thus, the first work I created is a catalogue of movements from the records obtained during the archive appropriation stage. In order to do that, I first visited the Faculty of Medicine at the Université Libre de Bruxelles to consult several books in the Physiotherapy and Physical Education sections and looked into the different formulations used to explain how the movement of the body is performed. For the cards in the catalogue, I chose to maintain the real image of the archived body and, on the other side, the 'translation' of the movement through my own body.

Figure 5. Carolina Bonfim, Detail of Catalogue de mouvements, 2017, 180 digital prints on A4 paper, binder, wood, metal, $100 \times 68 \times 45 \mathrm{~cm}$, MARCO,

Museo de Arte Contemporánea de Vigo.
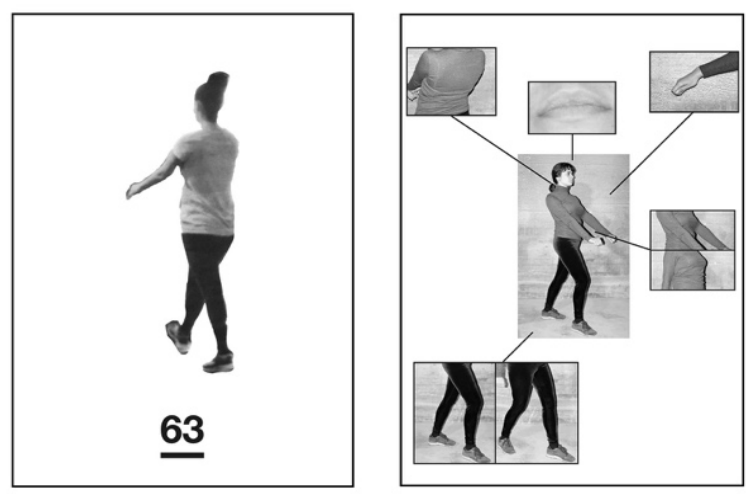

Source: Photo by Enrique Touriño.

The second piece consists of a set of panels showing each of the 'reference points' I had selected: face, mouth, shoulders, knees, and legs. This work is the result of an experiment based on photographic shots of each part of my body. Each photo was printed and fixed to a cardboard panel. The image gradually formed, emphasizing the lines, densities, and expressiveness of the body parts.
Figure 6. Carolina Bonfim, Panneau IV, 2017, c-print, wood, methacrylate, $171 \times 98 \times 5 \mathrm{~cm}$, MARCO, Museo de Arte Contemporánea de Vigo.

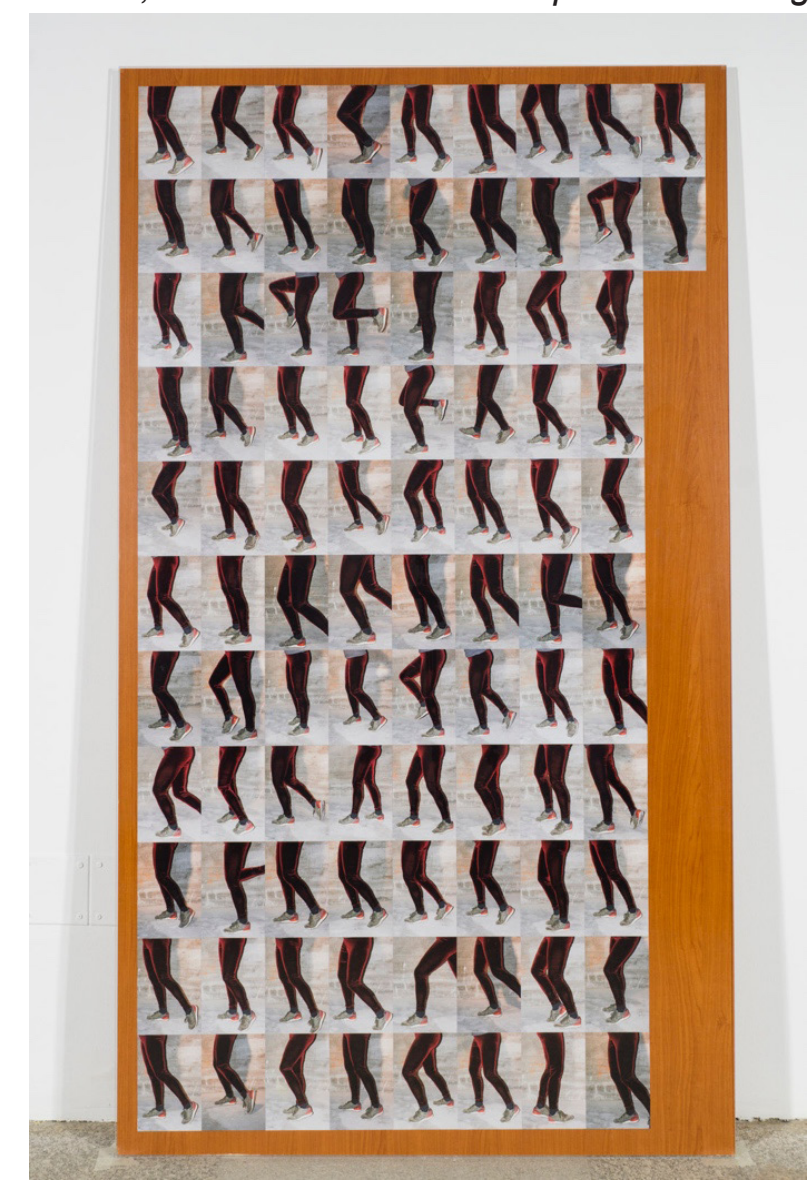

Source: Photo by Enrique Touriño.

The third piece I created is a video inspired by my rehearsal exercises, carried outduring the appropriation and incorporation stages. The camera lens acts as a magnifying glass that zooms in on my body parts. This is the piece that shows - through a process of enacted movements - the transformation of my body. 
Figure 7. Carolina Bonfim, 90 mouvements sur TECHNOGYM G6508D, video frame, 2017.

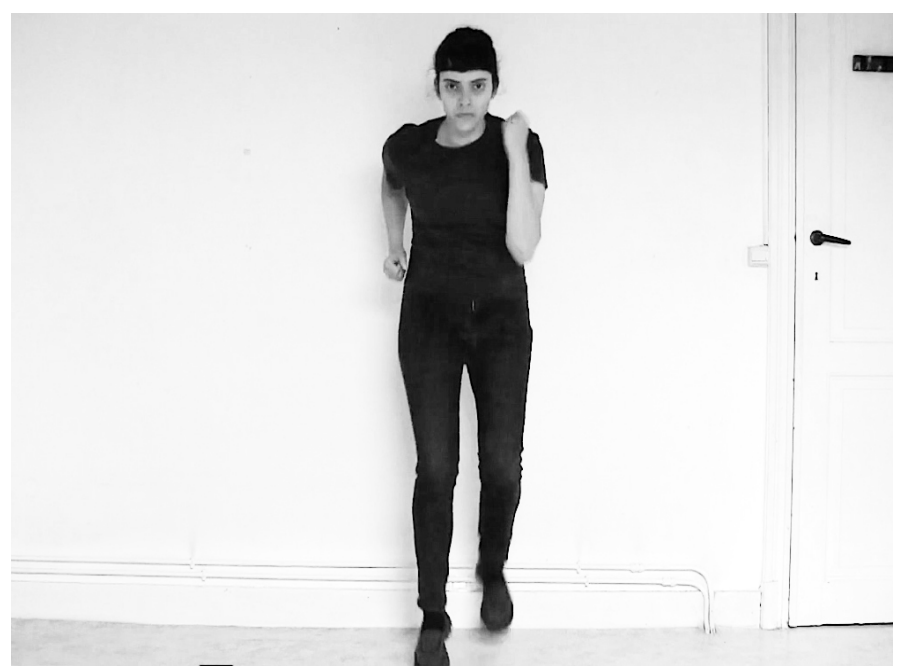

Source: Photo by Carolina Bonfim

These three works were shown in a solo exhibition entitled Ninety movements on TECHNOGYM G6508D ${ }^{4}$. After the exhibition, I took a step back in order to analyse the experience of doing this project and to understand my methodological and artistic approaches. As absurd and senseless as it may seem, or as close to the procedures of academic research it might also be, every artistic process has its own singular methodology. That reminded me of the exhibition Things that only an artist can do, co-curated by David Arlandis and Javier Marroquí at the Museo de Arte Contemporáneo de Vigo in 2010. This exhibition addressed the methodologies, attitudes, and technical approaches that twenty artists developed to carry out their projects. Walking through the different rooms of the museum, the visitor discovered - through records, notes, and traces about the process - how, for example, the artist Piero Golia became the first Italian to seek asylum in Albania or how Tere Recarens 'swept' the clouds over Berlin in order to let the sun shine on the city, or even how Xu Zhen invaded the borders of countries neighbouring China. Different from what we are used to seeing in museums, Things that only an artist can do invited the visitors to immerse themselves in the creative

4 For more information about the exhibition, see: www. marcovigo.com/es/node/2410, accessed 20 June 2020. processes and to imagine how these led to the artwork's finished form. Similarly, a practice-based research shares - through the structure of a thesis or an article - the process of creation in its details.

Although I find it most interesting to know how the audience or reader relates to the discovery of the creative process, for the purposes here I want to highlight what impact discovering the methodologies of my doctoral research had on my own work afterwards. Maybe, if I had not created this project within the framework of a PhD, I would not have taken this into account. I have the impression that I have revealed or systematized something that came out of intuition, and that the act of writing this down, naming each step, and formulating the sensations I felt, has made me aware of something I did not care to rationalize before. Writing or even reflecting about the process of creation in its details and in dialogue with other voices and discourses (from artists, theorists, etc.) did not come easily to me until I put my work in dialogue with the academic framework. If the act of writing is, for some artists, a way to understand perceptions that otherwise would be forgotten, for someone else - myself included - it can reveal something that may affect the way you work completely.

By revealing the procedures of my own practice, it is as if the desire to archive the other into my own body was lost. As said, Ninety movements on TECHNOGYM G6508D follows a series of works that I have been carrying out in recent years. Since 2010, I have been studying actions we regard as trivial: walking, swimming, running, drinking, looking, dancing, sitting, and moving around, among others. Now I can see how all these experiments of observing and archiving other bodies have always followed the same pattern. In A Choreographer's Handbook, Jonathan Burrows asks, "How do we come back also sometimes to a position of passionate ignorance, enough to choose something, instead of knowing everything?" (2010, p. 22) ${ }^{5}$. Burrows' question about the reflection of the creative process accurately

5 BURROWS, Jonathan. A Choreographer's Handbook. London/New York, Routledge, 2010, p. 22. 
describes my feelings at that moment when each part of the process was so clear. I realize that articulating something that comes intuitively was at first not very pleasant, but the intense experience of doing and reflecting made me look for new ways of working or even rethinking whether I wanted to continue making art. As Mika Hannula, Juha Suoranta, and Tere Vadén suggest, artistic research is "about the self-reflective and self-critical processes of a person taking part in the production of meaning within contemporary art, and in such a fashion that it communicates where it is coming from, where it stands at this precise moment, and where it wants to go" $(2005, \text { p. 10) })^{6}$. Although I felt after Ninety movements on TECHNOGYM G6508D that my body no longer needed to experience the archives of others, the body as an archive still interests me as an object of study and has made me realize that I had to take a new path.

In conclusion, by describing the methodologies developed throughout this project, I see that many of the steps in this process have much to do with research, understood as 'scientific research'. Artists and theorists have in fact many things in common, such as imagination, speculation, introspection, chance, and especially, intuition. Indeed, artistic research understood as an activity of production, exploration, and reflection - whether or not it is punctuated by doubts, failures, attempts, or discoveries - has its part in any research process. Perhaps artistic practices can provide the university landscape with a new freshness through this singular way of dealing with the research process - often without hypothesis, without pre-established methods, and in a non-standard way.
HANNULA, Mika; SUORANTA, Juha; VADÉN, Tere. Artistic Research: Theories, Methods and Practices. Academy of Fine Arts, Helsinki: Finland and University of Gothenburg, Sweden, 2005.

Recebido: 29/03/2021

Aceito: $17 / 05 / 2021$

Aprovado para publicação: 29/05/2021

Este é um artigo de acesso aberto distribuído sob os termos de uma Licença Creative Commons Atribuição 4.0 Internacional. Disponível em: <http://creativecommons.org/licenses/by/4.0>.

This is an open-access article distributed under the terms of the Creative Commons Attribution License 4.0 International. Available at: <http://creativecommons.org/licenses/by/4.0>.

Ce texte en libre accès est placé sous licence Creative Commons Attribution 4.0 International. Disponible sur: <http://creativecommons.org/licenses/by/4.0>.

\section{References}

BURROWS, Jonathan. A Choreographer's Handbook. London/New York: Routledge, 2010.

6 HANNULA, Mika; SUORANTA, Juha; VADÉN, Tere. Artistic Research: Theories, Methods and Practices. Academy of Fine Arts, Helsinki, Finland and University of Gothenburg, Sweden, 2005, p. 10. 